\title{
Erratum to: First detection, clinical presentation and phylogenetic characterization of Porcine epidemic diarrhea virus in Austria
}

\author{
Adolf Steinrigl $1^{1 *}$, Sandra Revilla Fernández ${ }^{1}$, Friedrich Stoiber ${ }^{2}$, Jutta Pikalo ${ }^{1}$, Tatjana Sattler ${ }^{1,3}$ \\ and Friedrich Schmoll
}

Unfortunately, after publication of this manuscript [1], it was found that the Case Presentation section contained an error. The line that reads, "Veterinarians reported highly varying degrees of mortality (7-100 \%), but absent or low $(<1 \%)$ mortality" should instead read, "Veterinarians reported highly varying degrees of morbidity (7-100\%), but absent or low (<1\%) mortality."

\begin{abstract}
Author details
'Austrian Agency for Health and Food Safety, Institute for Veterinary Disease Control, Robert Koch Gasse 17, 2340 Mödling, Austria. ${ }^{2}$ Veterinary practice, Römerstraße 56, 4600 Wels, Austria. ${ }^{3}$ University of Leipzig, Large Animal Clinic for Internal Medicine, An den Tierkliniken 11, 04103 Leipzig, Germany.
\end{abstract}

Received: 25 January 2016 Accepted: 26 January 2016

Published online: 01 February 2016

\section{Reference}

1. Steinrigl A, Revilla Fernández S, Stoiber F, Pikalo J, Sattler T, Schmoll F. First detection, clinical presentation and phylogenetic characterization of Porcine epidemic diarrhea virus in Austria. BMC Vet Res. 2015;11:310. doi:10.1186/ s12917-015-0624-1.

\footnotetext{
* Correspondence: adolf.steinrigl@ages.at

'Austrian Agency for Health and Food Safety, Institute for Veterinary Disease Control, Robert Koch Gasse 17, 2340 Mödling, Austria
}

Submit your next manuscript to BioMed Central and we will help you at every step:

- We accept pre-submission inquiries

- Our selector tool helps you to find the most relevant journal

- We provide round the clock customer support

- Convenient online submission

- Thorough peer review

- Inclusion in PubMed and all major indexing services

- Maximum visibility for your research

Submit your manuscript at www.biomedcentral.com/submit 